type. In 'mulgas', most of the leaves point upwards, so that rain dribbles down the branches to soak into the ground beside the trunks. The Eucalyptus species that dominate 'mallee', on the other hand, present the branching aspect of a pollarded willow. None of these vegetation-types is exclusive, however. Spinifex may grow beneath 'mulga', and saltbush (Atriplex spp.), bluebush (Maireana spp.), or mitchell grass (Astrebla spp.), beneath 'mallee'. Soil nutrients are extremely low in concentration in this apparently climax vegetation.

Although rainfall is so erratic, it is sufficient to maintain a surprising growth of trees (Fig. 2), which depend upon subsurface water. The numerous gaps in the MacDonnell Range even contain pools of blue water, most of which are extraordinarily beautiful.

To the south-west of Alice Springs lies Palm Valley, beside Finke Gorge. Here Red Cabbage-palms (Livistona mariae) survive, isolated from all other naturallyoccurring palms by some $1,000 \mathrm{~km}$ of dry country. These Cabbage-palms are relicts from a wetter period, some 5,000 years ago, when the whole of Australia was covered with lush vegetation, including many palms; they have survived because the water-table is permanently not far below the surface of the soil in that part of the country.

Many cycads (especially Macrozamia macdonnellii) are found in the various glens, gaps, and gorges, of the MacDonnell Range. They, too, are relicts from a period when the climate of central Australia was milder than it is today. These cycads resemble small tree-ferns, having short, thick stems with a crown of frond-like leaves. They commonly live for hundreds of years. The reproductive organs are in the form of separate male, and larger female, cones, borne on different trees. Like Red Cabbage-palms, cycads also rely upon sub-surface water.

Heavy falls of rain are followed by booms in vegetation growth. These booms have traditionally been exploited to the maximum by cattle ranchers and sheep farmers, who have been blamed for over-estimation of the long-term stock-carrying capacity. The consequent overgrazing has resulted in erosion, by wind and water, of the bared soil. At the same time, however, it should be remembered that boom and bust are a natural result of the

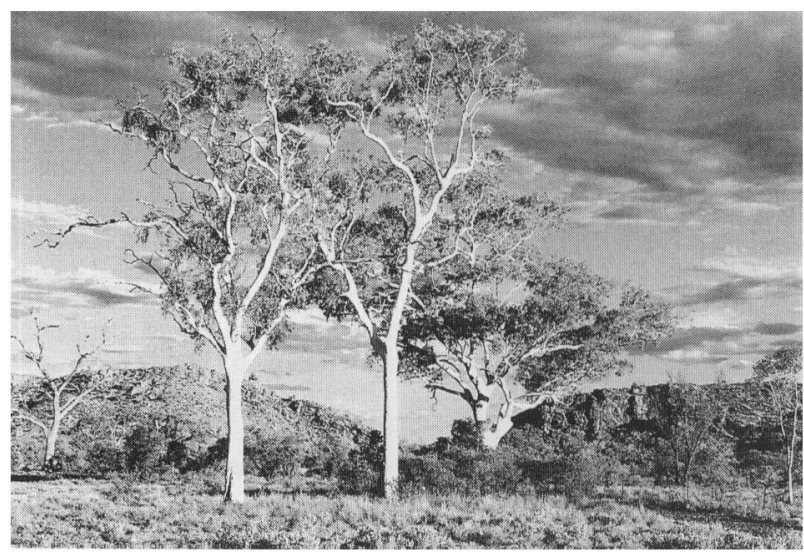

FIG. 2. Twin Gum-trees (Eucalyptus papuana), a well-known feature near Alice Springs (Diameter at breast height c. $0.5 \mathrm{~m}$ ). Photo: J.L. Cloudsley-Thompson.

unstable climate, and therefore not quite so unecological as they may at first appear.

More spectacular misjudgements of the consequences of land management practices include the impact of feral rabbits and foxes, the introduction of Prickly-pear (Opuntia inermis), the effects of uncontrolled irrigation, and excessive clearing of timber. The Australian Government has launched a number of measures, including over A $\$ 320$ (US \$240) millions to attack the problem of soil degradation. It is in the interest of the whole country that ecologically sustainable development should be achieved during the 'Year and Decade of Landcare'.

JOHN L. CLOUDSLEY-THOMPSON Emeritus Professor of Zoology Department of Biology (Medawar Building) University College London Gower Street London WCIE 6BT England, UK.

\title{
Protected Areas and Biodiversity: How the IVth Parks Congress Will Contribute*
}

Protected areas form the backbone of national and international efforts to conserve sites which are of particular value to society. Yet rising expectations coupled with declining budgets plague most sites at the very time when society needs protected areas more than ever. What can be done to enable protected areas to conserve biodiversity, save threatened species of plants and animals, and contribute in other ways to sustaining society?

The IVth World Congress on National Parks and Protected Areas will bring some 1,500 of the world's leading experts on protected areas to Caracas, Venezuela, from 10 to 21 February 1992, to address this question. Hosted by the Government of Venezuela and organized by IUCN, this once-a-decade Congress will set the agenda for action in the rest of the century, dealing especially with the difficult issue of finding support for protected areas in a time of increasing demand on resources and shrinking government budgets.

* See also the Important Prospect published on page 376 of this issue. $-\mathrm{Ed}$.
For the first time, this event will take place in a Latin American country. While the three previous Congresses (held in Yellowstone, Seattle, and Bali) primarily involved professionals directly concerned with protected areas, the IVth Congress will aim also to reach out to, and influence, the numerous other sectors of humanity that affect - and are affected by — protected areas. These include those who depend on the genes, species, and ecosystem resources, provided by protected habitats (such as local people, agriculture, forestry, fisheries, and pharmaceutical and other interests) as well as those who require services from natural habitats (water, timber, recreation, tourism, etc.).

As financial support for protected areas is a major concern of the Congress, numerous donor agencies will be invited to participate. A major effort will be made to involve the private sector as well, including nongovernmental organizations, relevant industries, local peoples' groups, tour operators and hotel managers, and local resource managers. Economists, regional planners, social 
cameras, will amount to US $\$ 147,000$. The International Photographic Council, a nongovernmental organization of the United Nations, will also offer two scholarships for young entrants ( 15 to 21 years old) in the form of a photographic correspondence course in English from the New York Institute of Photography.

UNEP's Executive Director Dr Mostafa K. Tolba offered the following comments concerning the competition: 'Climate changes, water pollution, forest destruction, air pollution and other environmental abuse, are already well advanced in many sectors of the world. The processes of environmental abuse are as destructive as nuclear war, and far less easy to avert. Never has humanity faced so crucial a decade as the $1990 \mathrm{~s}$. The most important demand at this critical time is for each and every political and business leader to develop a strong environmental awareness, and [to] take action to protect our irreplaceable planet. This photo[graphy] competition is based on the belief that the way in which we see our precious planet, as revealed through the eye of the camera, can inspire high social commitment and a driving sense of mission. We are looking forward to the participation of large numbers of photographers from many different countries.'

\section{Canon's President Enthusiastic}

President Dr Keizo Yamaji, of Canon, Inc., the supporting sponsor of the competition, commented: 'Canon is determined to excel as a global company capable of contributing to the world through our corporate philosophy of "Mutually Rewarding Coexistence." To achieve this goal, we are taking a serious and international stand on the environmental challenge of the $21 \mathrm{st}$ century.'

"With the focus on our "E" (for ecology, energy, and environment) Operations,' Dr Yamaji said, 'We are making a major effort for protecting the environment and preserving natural resources. Specific projects include recycling cartridges for Canon personal copiers and laserbeam printers, developing solar cells as a source of clean energy and cleaner manufacturing processes without using any chlorofluorocarbon, and creating more comfortable office environments as well on our own initiative. As a truly global corporation, Canon are thus propelled by a dedication for ecological concerns. We are extremely honoured to have the opportunity to cooperate in the sponsorship of this UNEP photo[graphic] competition, which we intend to utilize as one vital venue in putting our corporate philosophy to work.'

The competition is also supported by the United Nations Department of Public Information (UNDPI), the United Nations Conference on Environment and Development (UNCED), and the International Photographic Council (IPC). Support is also being provided by Varig Brazilian Airlines, Japan Airlines, and Eastman Kodak Company.

\author{
TORE J. BReviK, Chief \\ Information and Public Affairs \\ United Nations Environment Programme \\ PO Box 30552 \\ Nairobi, Kenya.
}

scientists, and anthropologists, will be invited, so as to enhance the flow of ideas between professionals concerned with protected-area management and those interested in wider environmental and conservation issues. Participation will be only by invitation from IUCN's Director-General.

Co-sponsors of this event will include the governments of The Netherlands, Sweden, Canada, USA, and Australia, WWF, The United States Nature Conservancy, the MacArthur Foundation, FAO, the World Bank, UNEP, UNESCO, and many others. Over the nearly twoweeks' period, participants will be actively involved in a diversity of plenary sessions, symposia, workshops (which will be the 'core' of the Congress), training courses, demonstrations, posters, technical field-trips, exhibitions, and cultural events.

The Congress is designed to produce a number of specific outputs, requiring that all participants come prepared to contribute very actively to the workshops and other events. Results expected from the Caracas Congress include a large number of publications, an action plan, a declaration for the forthcoming UN Conference on Environment and Development, a set of recommendations, and a protected-areas investment portfolio. It is hoped subsequently to publish a book describing the main proceedings. The Congress will also be the occasion for the release of the Global Biodiversity Strategy on 11 February 1992.

\author{
JEFFREY A. MCNEELY, Secretary-General \\ IVth World Congress on National Parks \\ \& Protected Areas \\ clo IUCN Headquarters \\ Avenue du Mont-Blanc \\ 1196 Gland, Switzerland.
}

